\title{
ФОРМУВАННЯ ДИЗАЙН-МИСЛЕННЯ \\ ОСОБИСТОСТІ ЗАСОБАМИ КОУЧИНГУ \\ ТА ТРАНСФОРМАЦІЙНОӤ ГРИ В ПРОЦЕСІ НАБУТТЯ ХУДОЖНЬО-ПРАКТИЧНОЇ КОМПЕТЕНТНОСТІ
}

\section{Масвська О. М.}

\section{ВСТУП}

Ідеї, інновації, трансформації - це безцінний ресурс кожної особистості, який необхідно розвивати 3 раннього віку. Запити й виклики сучасного суспільства мотивують людину синтезувати дієві методи і прийоми 3 різних сфер (бізнесу, освіти, спорту, економіки, мистецтва) для реалізації власних завдань. Швидкоплинність життя, контраст перенасиченості дешевого й часто не зовсім потрібного з дефіцитом якісного й необхідного спонукає до пошуку балансу. Цьому сприяє художньо-практична компетентність, що полягає у сформованості спеціальних умінь, навичок, прагнення до творчої самореалізації, набуття досвіду практично-предметної діяльності й засвоєння цінностей художньої культури ${ }^{1}$. Одним iз методів формування такої компетентності та вирішення професійно-практичних завдань $є$ дизайн-мислення (англ. design thinking) - творча діяльність, креативне сприйняття, переосмислення та відтворення, розроблення нестандартних інноваційних продуктів, сервісів та послуг, що зорієнтовані на людину і які не є можливими без спільної творчо-експериментальної роботи команди, глибокої емпатії, мозкового штурму, що вимагають розвитку «гнучких навичок» (англ. soft skills), які застосовуються у взаємодії між людьми та в будь-якому виді діяльності.

У процесі набуття художньо-практичної компетентності дизайнмислення формується під впливом різних чинників засобами коучингу та трансформаційної гри. Тьютор, тренер, коуч, ігротехнік та ігропрактик - це наставники, професіонали розвитку особистості, що використовують у своїй діяльності принципи роботи в команді, партнерство, тренування навичок, прикладні ігри. Ці принципи застосовуються i в освіті, проте лише для загального розвитку здобувача або передання предметних знань від учителя до учнів.

\footnotetext{
${ }^{1}$ Кравченко Л.М., Маєвська О.М. Свропейський досвід формування художньопрактичної компетентності особистості. Мистецтво та освіта. 2017. № 3 (85). С. 6.
} 


\section{1. Формування дизайн-мислення особистості в процесі набуття художньо-практичної компетентності}

Оскільки все частіше вагомими чинниками сучасної економіки стають наука й освіта, то визначеність останньої як найбільш пріоритетної сфери життя і діяльності зумовлена новими вимогами цивілізації, яка демонструє перехід від індустріального виробництва до суспільства науково-індустріальних технологій. ЮНЕСКО проголосило XXI ст. «Ерою освіти» ${ }^{2}$. Вона $\epsilon$ тією галуззю, де результат орієнтований на перспективу. Необхідно прогнозувати потреби людини в майбутньому, враховуючи постійні зміни в суспільстві, щоб вибудувати актуальну парадигму сучасного навчання.

Відомий учений-прагматист і педагог XX ст. Д. Дьюї вважав, що новітня філософія освіти поступово вибудовує свій фундамент на ідеї про необхідність установлення тісного взаємозв'язку між плинним досвідом у всій його різноманітності та освітою ${ }^{3}$. Він прагнув до перетворення кожної школи в зародок суспільного життя, створення у ній діяльності, яка б відображала життя більш широкого соціуму і була б пронизана духом мистецтва, історії та науки. Правильно скерована активність особистості дає цінні результати замість того, щоб розсіятись або вилитись у форму безцільних скитань ${ }^{4}$. Ідеї американського педагога Д. Дьюї сприяли пошуку нових форм навчальної роботи (метод проєктів нині широко застосовують на уроках трудового навчання в українській школі), актуалізації принципу «навчання через діяльність», де праця була як мотивом навчання, так i його методом. Із метою реалізації цього принципу чільне місце в школі посідали ігри, імпровізації, екскурсії, художня творчість дітей, домоводство та інші види ручної праці, щоб «показати дітям основні потреби суспільства та засоби їх задоволення» ${ }^{5}$. Крім того, філософ уважав цінним тільки те, що корисно людям, що дає практичний результат і що направлене на благо всього суспільства ${ }^{6}$.

Ключовими принципами прагматичної педагогіки Д. Дьюї є те, що розум формується в процесі соціального досвіду; головним у діяльності людини $є$ процес становлення, а не буття як статичного стану;

2 Крисоватий А. Основні парадигми освіти та їх сутнісна характеристика. Психологія і суспільство. 2015. № 1. С. 114.

3 Освітологія: хрестоматія : навчальний посібник / укладачі: В.О. Огнев’юк, С.О. Сисоєва. Київ : ВП Едельвейс, 2013. С. 237.

${ }^{4}$ Дьюи Д. Школа и общество / пер. с англ. Г.А. Лучинского. Изд. 2-ое. Москва, 1924. С. 38-41.

5 Історія педагогіки : навчальний посібник / за ред. М.В. Левківського, О.А. Дубасенюк. Житомир : Житомирський держ. пед. ун-т, 1999. С. 81.

${ }^{6}$ Рогозіна Л.А., Негур А.А., Залюбівська О.Б. Педагогічні ідеї Д. Дьюї у світлі сучасних освітніх тенденцій. Матеріали XLVI науково-технічної конферениї підрозділів ВНТУ : зб. доповідей. Вінниця : ВНТУ, 2017. С. 146. 
«основним інструментом» індивіда $\epsilon$ інтелект, за допомогою якого він розв'язує проблеми, що мають сприяти пристосуванню людини до навколишнього середовища і бути практично спрямованими; головне це не кількісні характеристики знань, набутих учнями у школі, а вміння використовувати їх у певній ситуації; навчання через досвід ${ }^{7}$. В одній зі своїх праць Д. Дьюї вказує на те, що «проблема встановлює ціль для думки, а ціль контролює перебіг мислення» ${ }^{8}$. Він уперше «поєднав» пізнання і діяльність у навчальному процесі, при цьому умовно розділивши його на кілька таких етапів, як відчуття проблеми, виявлення ii природи i суті, знаходження можливого рішення, обмірковування можливих наслідків знайденого рішення, подальші спостереження й експерименти, на основі яких можна зробити конкретний, позитивний або негативний висновок. Кожен 3 етапів стимулює суб'єктів навчання до активної інтелектуальної діяльності, дозволяє їм одержати практичний досвід в ухваленні й осмисленні рішень, а також допомагає максимально розкрити їх потенціал за рахунок відсутності жорстких меж і можливості знайти індивідуальне рішення тієї чи іншої проблеми ${ }^{9}$. Описані етапи відповідають процесам дизайн-мислення (конструювання як способу мислити), які виділив Г. Саймон (Herbert Simon) у своїй книзі «The Sciences of the Artificial» ${ }^{10}$ у 1969 р. На думку вченого, дизайн за своєю суттю $\epsilon$ перетворенням того, що існує, в бажане, будучи процесом, який зорієнтований на створення кращого майбутнього, інноваційних продуктів та послуг, на пошук нових рішень для комплексних проблем у різних сферах ${ }^{11}$; за його версією, в дизайн-мисленні можна виділити сім етапів:

1) визначення проблеми (емпатія, розуміння) - з'ясування потреб, які необхідно задовольнити, постановка і розуміння завдання (має бути доступним та здійсненним);

2) фокусування (аналіз і синтез) - зведення обмеженої кількості потреб для отримання інсайтів, формулювання точки зору для зосередження на визначенні питання і створенні критеріїв оцінки ідей;

${ }^{7}$ Огієнко О. Тенденції розвитку проектної технології у зарубіжній педагогіці ХХ століття. Порівняльна професійна педагогіка. 2011. № 1. С. 34.

8 Дьюи Д. Психология и педагогика мышления. Москва : Совершенство, 1997. С. 20-21.

${ }^{9}$ Рогозіна Л.А., Негур А.А., Залюбівська О.Б. Педагогічні ідеї Д. Дьюї у світлі сучасних освітніх тенденцій. Матеріали XLVI науково-технічної конференції nідрозділів ВНТУ : зб. доповідей. Вінниця : ВНТУ, 2017. С. 146.

${ }^{10}$ Simon H.A. The Sciences of the Artificial. London : MIT Press. 1996. 241 p.

11 Заббарова А.А. Система дизайн-мышления: этапы создания и особенности использования. Сборник научных статей VII Международного молодежного симпозиума по управлению, экономике и финансам. Казань : Казанский (Приволжский) федеральный университет, 2018. С. 289-292. 
3) формування (генерація) ідей - створення розгалуженого «дерева» численних концепцій та результатів для подальшої побудови прототипів. На цьому етапі можна застосувати техніки, що активують творчість, зокрема мозковий штурм (англ. brainstorming), бодістормінг (англ. bodystorming), скетчинг (англ. sketching), SCAMPER, створення мапи думок (англ. mind mapping), дерева проблем і дерева рішень, тріади критеріїв для відбору;

4) виготовлення прототипів - матеріалізація кількох ідей. Головними вимогами до цього етапу є швидкість та низькі фінансові затрати. Важливо, що цінними є не самі прототипи (не варто до них емоційно прив'язуватися), а досвід та знання, отримані в процесі взаємодії з ними, зворотний зв'язок від інших людей;

5) вибір кращого рішення (експериментальне тестування). Правилом на цьому етапі $\epsilon$ виготовлення прототипу, вважаючи, що маєш рацію абсолютно в усьому, але тестувати його треба так, ніби знаєш, що в усьому є помилка;

6) утілення рішення - створення і впровадження розробки;

7) оцінка результатів (зворотний зв'язок) - важливий етап, на якому визначають необхідність доопрацювання продукту чи його заміни ${ }^{12}$.

Послідовність етапів може змінюватись, проводитись одночасно різними групами в межах команди. Можна повторювати їх стільки разів, скільки потрібно для досягнення поставленої мети і вирішення проблеми. Головним $є$ правильне формулювання питань, виникнення i фіксація інноваційних ідей та відбір кращих рішень. У процесі обміну думками, успіхами й невдачами попереднього досвіду формується дух вільного спілкування, тренуються комунікативні навички, тобто відбувається успішна соціалізація.

Повертаючись до педагогічної теорії Д. Дьюї (так званого «прогресивізму»), важливо пам'ятати, що «словесну пам'ять можна розвинути уроками, можна набути певної сили думки шляхом занять математикою та іншими науками, але ці успіхи не витримують ні найменшого порівняння 3 розвитком уваги і сили суджень, котрі набуваються в роботі, яка має реальне внутрішнє спонукання до дій i реальні цілі» ${ }^{13}$. Різноманітність мотивів $\epsilon$ невичерпною, вони відрізняються як для дітей різного віку, так і для дорослих, залежно від оточення та життєвого досвіду. Значною помилкою $\epsilon$ нав'язування цілей ззовні (на прикладі «старої» української школи - рекомендації педагогам від керівництва, міністерства про те, як можна вивчати

${ }^{12}$ Саліженко Ю., Акименко К., Фронощук М. Давай по порядку: як влаштовано метод Design Thinking. Інтернет-журнал про інновації та культуру PLATFORMA. URL: http://bydesign.platfor.ma/stages-of-dt. (Дата звернення 27.04.2020).

${ }^{13}$ История образования конца XIX - начала XX вв. через призму актуальных педагогических теорий и практик : хрестоматия : учебное пособие / авт.-сост. Е.И. Пургина. Екатеринбург : Урал. гос. пед. ун-т, 2018. С. 127. 
умови, прогнозувати наслідки й обирати засоби діяльності, щоб максимально використати можливості різних конкретних ситуацій), адже при цьому інтелектуальна свобода самого вчителя обмежується цілями, що формуються «десь зверху». Рідко фахівець вільний від диктату підручника, методичної літератури, навчальної програми. Наслідком цього є недовіра 3 боку учня через конфлікт між власними природними цілями i поставленими йому школою, часто незрозумілими. Поки не буде визнаним демократичний принцип непорушної значущості будь-якого досвіду, доти не буде можливим подолання дискомфорту, породженого необхідністю пристосовування до зовнішніх цілей. Ціль можна визначити як можливий результат певного природного процесу, який стає фактом свідомості і фактом, що враховується при вивченні умов та визначенні подальших способів дії. Наявність цілі означає, що діяльність стала розумною. Різноманітність сформульованих цілей для педагога $є$ тим самим, що й велика кількість гіпотез для вченого-дослідника ${ }^{14}$.

Дизайн-мислення часто називають різновидом нестандартного мислення, що примушує вийти за межі відомого (англ. out-of-theboxthinking $)^{15}$. Це гнучкий підхід до створення інновацій, що об'єднує в собі дивергентне і конвергентне мислення, яке потрібно стимулювати 3 дитячого віку. Цьому чудово сприяють шкільні творчі заняття, зокрема образотворче мистецтво, трудове навчання. Жоден предмет так не розвиває уваги, спостережливості і послідовності, вміння бачити всі частини і їх співвідношення 3 цілим, як естетичні враження ${ }^{16}$, які можна отримати на цих уроках. Застосування групової та командної роботи дозволяе сформувати актуальні в наш час «м'які» навички особистості, зокрема комунікативні вміння, ситуаційну обізнаність, адаптивність та гнучкість, дипломатичність і тактовність.

Крім спеціальних умінь, визначальними компонентами художньопрактичної компетентності є прагнення до творчої самореалізації, тобто самомотивація (сформоване внутрішнє спонукання до виконання певної художньої роботи), засвоєння цінностей мистецтва, естетичного бачення, сприйняття, розуміння образотворчих творів. Великі можливості для ознайомлення зі світовою та українською художньою культурою, традиційною символікою дає сучасне обладнання інформаційно-комунікативні технології.

${ }^{14}$ История образования конца XIX - начала XX вв. через призму актуальных педагогических теорий и практик : хрестоматия : учебное пособие / авт.-сост. Е.И. Пургина. Екатеринбург : Урал. гос. пед. ун-т, 2018. С. 101-102.

15 Дизайн-мышление. URL: https://mpei.ru/Life/psycholog/Documents/ Дизайнмышление.pdf. (Дата обращения 26.04.20).

${ }^{16}$ История образования конца XIX - начала XX вв. через призму актуальных педагогических теорий и практик : хрестоматия : учебное пособие / авт.-сост. Е.И. Пургина. Екатеринбург : Урал. гос. пед. ун-т, 2018. С. 133. 
Зважаючи на події першої половини 2020 р., які вплинули на світову економіку і не могли не зачепити освітню сферу, варто звернути увагу, що перехід на дистанційне навчання актуалізував технічні засоби спілкування та викладання. Тому підходи для забезпечення якісних знань перейшли у сферу персональної комунікації, індивідуалізації процесу передання знань, що дало змогу вчителеві пристосувати методи й інтенсивність навчання відповідно до здібностей учня.

\section{2. Прийоми коучингу в процесі формування художньо-практичної компетентності й дизайн-мислення як її складника}

Трансформація творчого потенціалу особистості в художньопрактичну компетентність здійснюється під час реалізації цікавих креативних проєктів. Це може бути бізнес, сфера послуг, спорт, освіта. Поняття коучингу (англ. coaching) передбачає набір інструментів та методик для досягнення поставленої цілі.

Загальновідомо, що цей термін утворився від назви професії «коуч» (англ. coach), яка в кінці XIX ст. означала «спортивний тренер». Але в англійській мові є різниця між поняттями «trainer» i «соасh». Якщо завданням тренера $є$ навчання певних навичок, то для коуча - це розкриття внутрішнього потенціалу особи й допомога в досягненні максимальних результатів ${ }^{17}$. Нині коучами вважаються фахівці, що спеціалізуються на розвитку вміння досягати поставленої мети, здатні підтримувати в реалізації запланованого, супроводжують людину до найвищих досягнень. Але коуч - це не психотерапевт, тьютор чи вчитель. Він, навіть не будучи експертом у сфері підопічного, $€$ партнером, спостерігає, ставить правильні питання, спонукаючи «клієнта» мислити усвідомлено й широко (запускає процес дизайнмислення), вислуховує, контролюючи, щоб поставлена ціль була досягнута. Коучинг може бути як індивідуальним, так і груповим.

Заходи карантину (переведення освітнього процесу на дистанційне навчання) сприяли поширенню інструментів індивідуального коучингу в освітній галузі. Педагоги працюють віддалено з кожним своїм учнем. Чужі слова можуть дати знання, але тільки власний досвід дає потрібні навички і розвиває дизайн-мислення.

У художньо-практичній роботі для створення навчальних проєктів потрібно зацікавити учнів i, відповідно, викликати в них бажання діяти креативно. Тут стають у пригоді бізнес-прийоми роботи із запереченнями та спортивний інтерес стати кращим, переможцем, лідером, адже прийшовши до школи, більшість учнів вимушені виконувати завдання за програмою, а перебуваючи вдома, необхідно саморганізуватися й працювати самостійно. Самодисципліна

\footnotetext{
17 Что такое коучинг. Кто такой коуч. URL: https://medium.com/почему-быи-да/что-такое-коучинг-кто-такой-коуч-4497462c02а5.(Дата обращения 27.04.20).
} 
і вмотивованість - це запорука успіху. Мотивація до самовдосконалення $\epsilon$ основою коучингового підходу. У реалізації навчального проєкту, використовуючи коучинг-техніки, вчені радять дотримуватися чотирьох етапів:

Eman 1: Чого ти хочеш досягти? Особа ставить перед собою завдання, яке буде виконувати, визначає кінцеву мету і результат, до якого прагне.

Eman 2. Як ти можеш иього досягти? Разом із педагогом-коучем необхідно узгодити ті методи (технологію і прийоми), за допомогою яких результат буде успішним.

Eman 3. Як ти себе підтримаєш у тому разі, коли щось піде не так? Оскільки коучинг стимулює власні ресурси людини, то спосіб подолання психологічних наслідків невдачі має бути індивідуальним, адже він залежить від сприйняття і мислення особистості. Негативний досвід $\epsilon$ також досвідом, бо, допускаючи помилок, можна випадково «вхопити» інноваційну ідею.

Eman 4. Що ти отримаєш як результат? Крім матеріалізованого задуму (готовий проєкт - це, наприклад, виготовлена річ), важливо розуміти, яких інсайтів та досвіду набуває учень, які навички вдосконалює ${ }^{18}$.

Творче мислення, як і м'язи, можна тренувати. Ще однією дієвою коучинг-технікою є Стратегія Діснея. Ця вправа підхожа для створення плану i творчого рішення завдання. Уважається, що автором $\epsilon$ B. Дісней (Walt Disney), котрий ділив своїх співробітників на три команди, розміщуючи їх на різних поверхах будівлі. Другий поверх, де через великі вікна було видно панорамні пейзажі, займали «мрійники»- люди натхнення, ті, хто придумував нове, незвичайне, грандіозне. Вони могли малювати на стінах, годинами створювати повітряні фортеці. На першому поверсі розміщувалися «реалісти», завданням яких було переводити будь-яку ідею «мрійників» у план реалізації з прорахунком необхідних витрат. А в цокольному темному приміщенні 3 маленькими вікнами розміщувались «критики», котрі шукали найменші недоліки і помилки в проєктах реалістів і ніколи не перетинались із «мрійниками».

Вправа дозволяє «поспілкуватися» 3 кожною $з$ трьох сутностей, які, безперечно, $\epsilon$ в будь-якої людини. Для цього використовуються допоміжні засоби (мікрофони чи диктофони, стільці, капелюхи тощо). Кожному з трьох вибраних аксесуарів призначають роль і почергово, приміряючи на себе характеристики Мрійника, Реаліста чи Критика, обмірковують.

18 Заднепровская А., Тищук А. Простые и эффективные коучинг-техники инструкция по применению. URL: https://prohr.rabota.ua/prostyie-i-effektivnyiekouching-tehniki-instruktsiya-po-primeneniyu/. (Дата обращения 29.04.20). 
Починати варто з Мрійника. Потрібно уявити ціль, мрію, річ такою, якою б вона вже була реальною. Уголос описуючи свою фантазію максимально детально, можна вести запис на диктофон телефона або робити відеозапис для того, щоб не втратити ідею, чи занотувати придумане в блокнот. Що більш яскравою буде картинка, то більше інформації можна отримати.

Потім потрібно перейти на роль Реаліста і зробити уявлене більш реалістичним, зокрема розкласти ціль, використовуючи методику P. Ділтса ${ }^{19}$, за SMART-критеріями ${ }^{20}$, наприклад:

- Що знадобиться для виконання поставленого завдання?

- Якою має бути послідовність дій?

- Які ресурси потрібні насамперед?

- Скільки часу потрібно на реалізацію задуманого?

- Які знання, навички, таланти, хист будуть потрібні?

Завжди діє правило «одна ціль - один результат». Якщо при формулюванні завдання виявилось, що необхідно досягти декількох результатів, то кінцева мета має бути розділена на декілька завдань ${ }^{21}$.

Дуже важливо відрізняти в собі Реаліста від Критика, щоб завчасно не втратити віри у власні можливості. Окремо можуть з'явитися заперечення щодо нездійсненності ідеї, такі погляди варто записати окремо й тимчасово відкласти.

Коли попередній план буде складено, час перевтілитися в Критика. Але Критик має оцінювати не саму ідею (це $є$ ключовим моментом), а план-розробку Реаліста ${ }^{22}$. Допоміжні питання можуть бути такими:

- Які є недоліки чи слабкі місця?

- Чого не вистачає або що не враховано?

- Кому може не сподобатись ця ідея або що може завадити iіi реалізації?

- Що може зупинити на шляху досягнення поставленої мети?

Заперечення треба фіксувати доти, доки вони не вичерпаються. Після цього етапу педагог може допомогти з розбором пунктів, на які вказав «внутрішній критик» учня, i запропонувати відшукати аргументи для коригування моментів невпевненості. Педагог застосовує прийом «розкадровки» - конкретне заперечення передається

19 Пирамида Дилтса. URL: https://goal-life.com/page/method/piramida-diltsa (Дата звернення 29.04.20).

${ }^{20}$ Як правильно ставити цілі? URL: https://timehack.wordpress.com/2009/08/29/якправильно-ставити-цілі-технологія-s (Дата звернення 29.04.2020).

${ }^{21}$ Цели по SMART: подробный обзор. URL: http://powerbranding.ru/marketingstrategy/smart-celi/ (Дата обращения 29.04.2020).

22 Козлова O. Стратегия Уолта Диснея (инструкция). URL: https://prosto-coach.ru/instrumenty-kouchinga/strategiya-uolta-disneya-instruktsiya.html. (Дата обращения 29.04.2020). 
учневі, який повторно одягає капелюх Мрійника. Послідовно знову повторюють маршрут «Мрійник - Реаліст - Критик - Реаліст», допоки не закриються всі зауваження Критика. Після цього учень ставить собі запитання: «Який перший (найпростіший) крок у напрямі досягнення мети я готовий здійснити сьогодні?», адже «шлях у тисячі миль починається $з$ першого кроку» (Лао-цзи). Саме дія, творча діяльність стимулює дизайн-мислення і сприяє розвитку художньо-практичної компетентності.

\section{3. Трансформаційна гра як засіб формування дизайн-мислення особистості під час розвитку художньо-практичної компетентності}

A. Ейнштейн (Albert Einstein) стверджував, що не можна розв'язати проблему на тому ж рівні, на якому вона виникла, i 3 тим же мисленнями, яким вона створена, адже для цього необхідно покинути зону комфорту. Щоб не завести особистість у шоковий стан, потрібно поступово, невеликими кроками, ускладнюючи завдання, рухатися до зміни способу мислення. Для цього одним з інструментів $є$ гра. Навчальні ігри можуть бути цікавими для педагогів, бо за їх допомогою можна привести учнів до єдиного рівня знань, підвищити навчальну мотивацію. За допомогою гри процес навчання полегшується і стає більш привабливим. Важливою особливістю ігор $\epsilon$ те, що вони ефективні там, де отримані знання потрібно перевести в усвідомлені вміння, а в ідеалі - в несвідомі навички, тобто закріпити отриманий результат діями. Такий формат має стимулювальний вплив ${ }^{23}$.

Гейміфікація в освіті сприяе розвитку «гнучких навичок», надпрофесійної та надкомпетентісної майстерності, якою повинна володіти креативна особистість ${ }^{24}$. Ігрові технології не лише виховують пізнавальний інтерес до предмета гри та активізують діяльності учнів, але й тренують пам'ять, стимулюють розум, увагу. Це один із прийомів подолання пасивності учнів ${ }^{25}$.

Трансформаційна гра (далі - Т-гра) - це осмислена зміна в процесі непродуктивної діяльності, де мотив міститься не в результаті, а в самому процесі. Т-ігри не дають можливості виграти в когось, бо, по суті, це особистісна трансформація. Змагання звичайних ігор тут замінюється на взаємну підтримку, стимулюється активність,

${ }^{23}$ Галюк К.В. Обучающие игры. URL: https://websmart.center/article/743. (Дата обращения 29.04.20).

24 Галюк К.В. Вебінар «Гейміфікація освітнього процесу в школі необхідна складова результативного дистанційного навчання». URL: http://undip.org.ua/info/9889/. (Дата звернення 29.04.20).

${ }^{25}$ Костюкевич М.Г. Дослідження технологій створення освітніх комп'ютерних ігор : магіст. дис. : 171 Електроніка. Київ, 2019. С. 12. 
проявляються лідерські якості, а соціальна організація і комунікація виникають безумовно і без примусу.

На думку Д. Ельконіна, «у грі не лише розвиваються чи заново формуються окремі інтелектуальні операції, але й кардинально змінюється позиція (гравця) щодо навколишнього світу та формується механізм можливої зміни позиції й координації своєї точки зору 3 іншими можливими поглядами» ${ }^{26}$, адже прикладні ігри міняють мислення. Після них з'являється розуміння того, для чого варто опрацьовувати ту чи іншу інформацію, тренувати певні навички, фокусується реальна ціль та кроки для ії досягнення. Учасники навчаються одне в одного під час гри. Найменшим, чому гра може навчити, є планування. Дисципліна, що формується під час взаємодії в команді, самоорганізація та мотивація стимулюють силу волі, впевненість у своїх силах, підвищують самоцінність.

Цінності світової художньої культури, багатство народної традиції, символізм знаків та орнаментів на підсвідомому рівні надихає та програмує людину на креативне мислення. Переосмислення побаченого, міркування щодо свого сприйняття художньо-культурного надбання людства сприяє генеруванню інноваційних підходів у виконанні завдань для реалізації поставлених цілей.

Автор першої запатентованої технології створення гри «SMART Game» К. Галюк говорить, що для правильного розуміння призначення трансформаційної гри необхідно усвідомити, що «наш мозок має бути в резонансі з нашим бажанням, а в грі завжди $є$ запит, в основі якого лежить саме бажання людини-гравця» ${ }^{27}$. Особливістю Тгри $є$ те, що кожен бачить шлях розв'язання свого завдання.

Т-ігри дають розуміння цінності часу, адже час - це та цінність, яка $€$ у кожного, проте вартість часу різна і залежить від знань, навичок та дій особистості. Відома фраза «час - це гроші» стає дуже актуальною в процесі гри.

Для успішного формування художньо-практичної компетентності та дизайн-мислення можна запропонувати учням розробити власну гру. Потрібно ознайомити їх із принципом формулювання правил гри, завдань. Щоб визначитися 3 темою, метою, дизайном майбутньої гри, варто розділитись на робочі групи i, застосовуючи стратегію Діснея, створити поле для гри (ігрову карту), фішки (фігурки для гравців), бланки, картки завдань зі сформульованими запитами, завданнями, запитаннями, відповідями, що б утворювали комбінації в будь-якому розкладі гри. Колорит і загальний вигляд гри залежить від фантазії та

${ }^{26}$ Семенихина И. Трансформационные игры. URL: https://psychologyjournal.ru/ stories/transformatsionnye-igry/. (Дата обращения 29.04.2020).

27 Галюк К.В. Что мне может дать та или иная Т-игра? URL: https://websmart.center/article/763. (Дата обращения 29.04.2020). 
творчих навичок учнів. У процесі роботи можна вивчити значення кольорів та силу їх впливу на свідомість людини. Правила гри краще обмірковувати на етапах дизайн-мислення. Цінність проєкту буде для команди ще й у тому, що учасники зможуть більше дізнатися про інтереси одне одного, попрацювати в різних ланках, спробувати себе в чомусь новому, адже можна бути не лише користувачем, але й розробником, створювати продукт за власним запитом. Одним із таких запитів може бути подолання психологічних проблем перехідного віку.

Прикладом трансформаційної психологічної гри $\epsilon$ «Hatters», що перекладається як «майстри капелюхів». Авторкою гри $є$ професійний психолог Л. Смирнова ${ }^{28}$. У цій грі будь-яка ідея, думка чи мрія за допомогою мислення розглядається як основний ресурс особистості. За основу взято постулат Едварда де Боно, що якість людського мислення $\epsilon$ значущою для всіх рівнів (від окремо взятої особистості до глобального рівня).

Кістяк гри - це модель «шести капелюхів мислення» Едварда де Боно, котрий шляхом розподілу мислення на шість різних режимів оперує різними аспектами інформації. Гравець розчиняється у світі своєї ідеї. У процесі гри відкриваються напрями ії розвитку, перешкоди та випадковості. Після завершення гри учасник отримує позитивний емоційний заряд, безліч можливостей і нові думки, а головне - ухвалює рішення про те, бути сформульованій на початку гри ідеї чи відпустити iii, вивільнивши місце для нових.

Гру арткоуча Н. Непорожньої «Артпалітра» ${ }^{29}$ побудовано на основі методик арттерапії. Під час такої гри, досліджуючи свій запит, гравець проходить етап трансформації i наповнення ресурсами, використовуючи спеціальні техніки-арткартини, що сприяє розвитку дизайн-мислення.

«Мистецтво маленьких кроків» психолога, казкотерапевта й коуча Л. Акимової ${ }^{30}$ теж може стати одним 3 інструментів формування художньо-практичної компетентності, адже цю гру спрямовано на тренування навички планування i пошуку ресурсів для реалізації великих проєктів, а також на навчання перетворювати будь-яку ситуацію на вигідну собі та поставленій меті. У доступній формі гра дає зрозуміти те, що кожен має необхідні ресурси для досягнення бажаного, а їі процес дозволяє сформувати конкретний початковий план дій.

${ }^{28}$ Ирхина С. Каталог трансформационных игр. Київ : ТОВ НВП «Інтерсервіс», 2019. C. 19.

${ }^{29}$ Ирхина С. Каталог трансформационных игр. Киев : ТОВ НВП «Інтерсервіс», 2019. С. 29.

${ }^{30}$ Ирхина С. Каталог трансформационных игр. Киев : ТОВ НВП «Інтерсервіс», 2019. C. 101. 
Коучингова тренінгова гра «Код да Вінчі» (автором $є$ ігротехнік О. Бальде) ${ }^{31}$ дає можливість розширити творчий потенціал, покращити наявний талант, розкрити здібності, що не були розкриті і вивчені раніше, розвиває навички творчо мислити й діяти. Ця гра наповнює інсайтами, адже сім принципів розвитку творчості, які запропонував Леонардо да Вінчі, лягли в основу дизайну сегментів ігрового поля. Ці принципи не втратили своєї актуальності й нині:

- Curiosita - цікавість, безперервність навчання;

- Dimostrazione - незалежність мислення, експериментальна перевірка знань;

- Sensazione - гострота сприйняття, вдосконалення сприйняття;

- Sfumato - невизначеність, готовність прийняти невизначене;

- Scienza - урівноваженість логіки і фантазії (М. Гелб (Michael J. Gelb) уважав, що цьому найкраще сприяє малювання $\left.{ }^{32}\right)$;

- Corporalita - баланс тіла й розуму, вміння володіти своїм тілом;

- Connessione - діаграма зв'язків, системне мислення.

Завдяки впровадженню цих принципів у навчання можна вирішувати проблему кризи у творчості, шукати нові напрями діяльності, застосовувати мозковий штурм для гуртування однодумців.

Трансформаційна гра для учнів загальноосвітньої школи має враховувати вікові особливості гравців, адже особисті запити відрізняються. Якщо молодших підлітків можна зацікавити предметними технологіями, вивченням власних унікальних здібностей та особливостей, то для старших більш актуальною є профорієнтація та психологія відносин. Ігри такого виду вже створені для свідомих дорослих, проте нова трансформаційно-коучингова гра спеціально для формування художньо-практичної компетентності і дизайн-мислення зокрема перебуває на етапі розроблення. Потрібно не лише з'ясувати, якими інструментами буде стимульовано самомотивацію гравців, але й те, як передати знання та перевести їх у практичну сферу, щоб учасник міг закріпити їх у своїй діяльності. Для цього буде використано дизайн карт-завдань із творами митців образотворчості, які своїм естетичним виглядом будуть розвивати сприйняття $\mathrm{i}$ розуміння краси. Формулювання на картах стимулюють отримання власного інсайту щодо запиту в грі. Наприклад, якщо підліток має внутрішні блоки творчого мислення і фантазії, то, розгортаючи карту-завдання, він може надихнутися фоторепродукцією відомого митця або, відповідаючи на поставлене запитання, сформулювати концепцію своєї майбутньої творчої роботи чи проєкту. Ігрове поле створено таким чином, щоб ним

${ }^{31}$ Ирхина С. Каталог трансформационных игр. Киев : ТОВ НВП «Інтерсервіс», 2019. С. 124.

${ }^{32}$ Гелб М.Д. Научитесь мыслить и рисовать как Леонардо да Винчи: семь шагов к гениальности каждый день. М. : Попури, 2004. 432 с. 
можна було переміщувати фішку нелінійно, виконуючи поставлене попереднім ходом завдання і загальний запит. Напрями ходу керуються цифрами на ігрових кубиках, один із яких позначає горизонталь, а інший - вертикаль. Таким чином, підліток знаходить прихований ресурс у підсвідомості та розуміє те, що саме допомагає йому бути творчим. Оскільки художньо-практична компетентність уміщує прагнення до творчої самореалізації, то завдання будуть спрямовані на пошук сфери діяльності особисто для гравця, у якій цей принцип може бути здійснений.

Набути базового досвіду практично-предметної діяльності можна в 5-7 класах на уроках трудового навчання й образотворчого мистецтва, виконуючи цікаві проєкти, а учні старшого шкільного віку реалізують свій потенціал у дизайні, моделюванні, заняттях рукоділлям, кулінарії, художньому обробленні шкіри, шитті, вишиванні, плетінні, малюванні, ліпленні, різьбленні з каменю, дерева тощо. Ключовим аспектом $є$ пошук інтересу до творчої дії, свобода індивідуального вподобання. Як наслідок, гарантована поява мотивації та задоволення як від гри (наповнення енергетичним ресурсом), так і від отриманого в процесі практично-предметної діяльності результату (матеріалізований задум).

Унікальністю трансформаційних ігор також $\epsilon$ можливості тренування фактору «випадковостей», що трапляються і часто вносять корективи в план досягнення бажаного результату. Нелінійність руху полем гри i робота 3 «випадковими» завданнями, труднощами, вправами дає тисячі варіантів розвитку гри. Щоразу рух полем унікальний i допомагає вибудувати індивідуальну схему запитань $\mathrm{i}$ запитів ${ }^{33}$. Важливою $\epsilon$ психологічна екологічність, демонстрація підтримки в процесі гри. У цьому можна переконатись, взявши безпосередню участь у грі. Елемент гри в особистісних трансформаціях знімає стресове напруження, дає сильні інсайти. Командна гра має елементи тренінгу, але при цьому дозволяє індивідуально проходити різні завдання й отримувати власний досвід. Саме тому ведучий гри має бути професіоналом, психологом, коучем, адже для цього необхідні спеціальні знання i вміння, проте педагог також може отримати потрібні навички, пройшовши відповідний навчальний курс.

Отже, застосування авторських прикладних коучинговотрансформаційних ігор в освіті має здійснюватись професійними ігропрактиками. Уведення в освіту елементів трансформаційної гри дозволить розвинути в дітях самодіяльність, особисту відповідальність i приведе їх до реалій життя. Безпечне середовище, контроль модератора-ведучого, чіткі правила й умови забезпечують досягнення результату. Трансформація відбувається м'яко й невимушено. Т-ігри

33 Галюк К.В. Целесообразность. Двигаться к желаемому с образом цели. URL: https://websmart.center/article/767. (Дата обращения 29.04.2020). 
схожі на роботу з метафоричними картами, але тренують свідомість перебувати в новому незвичному просторі.

Завдяки розвитку інформаційно-комунікаційних технологій проведення Т-ігор доступне як в онлайн-режимі, так і особисто. Перевагою дистанційної гри $є$ те, що зіграти може більша кількість людей одночасно і зібратись у зручний для всіх час та в комфортній обстановці, при цьому перебуваючи географічно віддалено. На противагу цьому в занадто оцифрованому світі варто розвіртуалізуватись і спілкуватися безпосередньо, бути фізично присутнім. Кількість гравців може варіюватися. Ефективність вища, коли за ігровим полем збирається до восьми осіб. Саме ігровий момент дозволяє отримати задоволення від процесу як дітям, так і дорослим. У трансформаційні ігри нині грають статусні бізнесмени, топові дизайнери, креативні викладачі. Це нова галузь для розвитку власних здібностей, розкриття свого потенціалу.

\section{ВИСНОВКИ}

Уміння творчо підходити до вирішення життєвих ситуацій, робочих питань, систематизація та правильне оброблення інформації - незамінні риси людини XXI ст. Розвиток просторового, критичного, креативного мислення, розкриття своїх здібностей, бажань, розуміння себе, досягнення високих результатів $\epsilon$ необхідними для успішної самореалізації особистості. Зацікавленість науковців, серед яких економісти, соціологи, психологи та інші, інструментами дизайнмислення підвищує інтерес до цієї проблеми та актуалізує використання його принципів у навчанні.

Дизайн-мислення як основа художньо-практичної компетентності, може бути використане в різних сферах (від бізнесу до спорту, від промисловості до освіти). Інтеграція прийомів і технік з однісї галузі в іншу сприяє кращому взаєморозумінню та комунікації.

Перевагою дизайн-мислення $є$ позитивне сприйняття помилки, коли будь-яка помилка може стати ідеєю чи інновацією. Дизайн-мислення дозволяє знизити психологічну відповідальність за ухвалення рішень, виводить із творчої кризи через формат мікродій, збирає команду 3 колективу, допомагає глибоко зануритися в причини дій і поведінки людей, а прийоми коучингу та трансформаційної гри формують у свідомості вміння ставити цілі, шукати рішення, мотивувати себе.

Поетапний розвиток художньо-практичної компетентності може відбуватися протягом життя. У шкільні роки формується іiі міцна основа засобами образотворчого мистецтва, дизайну, трудового навчання. Коучингова підтримка важлива на будь-якому етапі особистісного зростання. Коучинг допомагає завжди бути в ресурсі, визначити свій талант, реалізувати його, стати лідером. Люди, що досягають своєї мети, роблять все для цього. Ігровий метод у поєднанні 
3 коучингом розвиває відчуття соціальної співпраці. Застосування коучингових технік, трансформаційної гри в ранньому віці гарантує готовність індивіда до труднощів майбутнього.

Малодослідженість у науковій літературі розглянутих засобів впливу на потенціал особистості дає широкий спектр подальших пошуків у цьому напрямі.

\section{АНОТАЦІЯ}

У статті висвітлено результати дослідження проблеми формування дизайн-мислення як основи художньо-практичної компетентності особистості. Визначено сутність поняття «художньо-практична компетентність». Виявлено передумови виникнення методу дизайнмислення для вирішення освітніх завдань. Висвітлено етапи дизайнмислення, на яких доцільно застосовувати прийоми коучингу. Їх актуалізація зумовлена новими запитами суспільства (освіта в умовах карантину). Доведено, що формування художньо-практичної компетентності має стати одним із важливих завдань сучасної освіти в підготовці індивіда до творчої реалізації власних інноваційних ідей та розв'язання різних життєвих ситуацій, проблем і завдань. Створення трансформаційної гри, одним із завдань якого буде включення до дизайн-мислення компонента художньо-практичної компетентності, дозволить на прикладі уроків трудового навчання й образотворчого мистецтва загальноосвітньої школи показати методику використання досліджуваних інструментів.

\section{ЛIТЕРАТУРА}

1. Галюк К.В. Вебінар «Гейміфікація освітнього процесу в школі необхідна складова результативного дистанційного навчання». URL: http://undip.org.ua/info/9889/ (Дата звернення: 29.04.2020).

2. Історія педагогіки : навчальний посібник / за ред. М.В. Левківського, О.А. Дубасенюк. Житомир : Житомирський держ. пед. ун-т, 1999. 336 с.

3. Костюкевич М.Г. Дослідження технологій створення освітніх комп'ютерних ігор : магіст. дис. : 171 Електроніка. Київ, 2019. 158 с.

4. Кравченко Л.М., Маєвська О.М. Європейський досвід формування художньо-практичної компетентності особистості. Мистеитво та освіта. 2017. № 3 (85). С. 6-10.

5. Крисоватий А. Основні парадигми освіти та їх сутнісна характеристика. Психологія і суспільство. 2015. № 1. С. 114-121.

6. Огієнко О. Тенденції розвитку проектної технології у зарубіжній педагогіці ХХ століття. Порівняльна професійна педагогіка. 2011. № 1. C. 31-38.

7. Освітологія: хрестоматія : навчальний посібник / укладачі: В.О. Огнев’юк, С.О. Сисоєва. Київ : ВП Едельвейс, 2013. 744 с. 
8. Рогозіна Л.А., Негур А.А., Залюбівська О.Б. Педагогічні ідеї Д. Дьюї у світлі сучасних освітніх тенденцій. Матеріали XLVI науковотехнічної конферениії підрозділів ВНТУ : зб. доповідей. Вінниця : ВНТУ, 2017. С. 146-149.

9. Саліженко Ю., Акименко К., Фронощук М. Давай по порядку: як влаштовано метод Design Thinking. Інтернет-журнал про інноваціï ma культуру PLATFORMA. URL: http://bydesign.platfor.ma/stages-of-dt. (Дата звернення: 27.04.2020).

10. Як правильно ставити цілі? URL: https://timehack.wordpress.com/ 2009/08/29/як-правильно-ставити-цілі-технологія-s. (Дата звернення: 29.04.2020).

11. Галюк

K.B.

Обучающие

игры.

URL: https://websmart.center/article/743. (Дата обращения: 29.04.2020).

12. Галюк К.В. Целесообразность. Двигаться к желаемому с образом цели. URL: https://websmart.center/article/767. (Дата обращения 29.04.2020).

13.Галюк К.В. Что мне может дать та или иная Т-игра? URL: https://websmart.center/article/763. (Дата обращения 29.04.2020).

14.Гелб М.Д. Научитесь мыслить и рисовать как Леонардо да Винчи: семь шагов к гениальности каждый день. Москва : Попури, 2004. 432 c.

15. Дизайн-мышление. URL: https://mpei.ru/Life/psycholog/ Documents/ Дизайн-мышление.pdf. (Дата обращения: 26.04.2020).

16. Дьюи Д. Психология и педагогика мышления. Москва : Совершенство, 1997. 208 с.

17. Дьюи Д. Школа и общество : руководство / пер. с англ. Г.А. Лучинского. Изд. 2-ое. Москва : Государственное изд-во, 1924. $174 \mathrm{c}$.

18. Заббарова А.А. Система дизайн-мышления: этапы создания и особенности использования. Сборник научных статей VII Международного молодежного симпозиума по управлению, экономике и финансам. Казань : Казанский (Приволжский) федеральный университет, 2018. С. 289-292.

19. Заднепровская А., Тищук А. Простые и эффективные коучингтехники - инструкция по применению. URL: https://prohr.rabota.ua/ prostyie-i-effektivnyie-kouching-tehniki-instruktsiya-po-primeneniyu/ (Дата обращения: 29.04.2020).

20. История образования конца XIX - начала XX вв. через призму актуальных педагогических теорий и практик : хрестоматия : учебное пособие / авт.-сост. Е.И. Пургина. Екатеринбург : Урал. гос. пед. ун-т, 2018. 204 c.

21.Ирхина С. Каталог трансформационных игр. Изд. 4. Киев : ТОВ НВП «Інтерсервіс», 2019. 226 с. 
22. Козлова O. Стратегия Уолта Диснея (инструкция). URL: https://prosto-coach.ru/instrumenty-kouchinga/strategiya-uolta-disneyainstruktsiya.html. (Дата обращения: 29.04.2020).

23. Пирамида Дилтса. URL: https://goal-life.com/page/method/ piramida-diltsa. (Дата обращения: 29.04.2020).

24. Семенихина И. Трансформационные игры. URL: https://psychology journal.ru/stories/transformatsionnye-igry/. (Дата обращения: 29.04.2020).

25. Цели по SMART: подробный обзор. URL: http://powerbranding.ru/ marketing-strategy/smart-celi/. (Дата обращения 29.04.20).

26. Что такое коучинг. Кто такой коуч. URL: https://medium.com/ почему-бы-и-да/что-такое-коучинг-кто-такой-коуч-4497462c02а5. (Дата обращения: 27.04.2020).

27. Simon H.A. The Sciences of the Artificial. London : MIT Press. 1996. $241 \mathrm{p}$.

\section{Information about the author:}

Maievska O. M.,

PhD Student at the Department of Theory and Methodic of Technological Education

Poltava V. G. Korolenko National Pedagogical University 2, Ostrohradsky str., Poltava, 36000, Ukraine 